\title{
GLOBÁLIS TUDÁSBÁZIS SZEMANTIKUS WEB ALAPOKON
}

\author{
Szerző: \\ Roskó Tibor \\ Debreceni Egyetem
}

Szerző e-mail címe:

r.tibor92@gmail.com

\section{Lektor:}

Adamkó Attila

Debreceni Egyetem,

Mező Ferenc

Debreceni Egyetem

Szilágyi Barnabás

Debreceni Egyetem

Nemes Magdolna

Debreceni Egyetem

Roskó Tibor (2016): Globális tudásbázis szemantikus WEB alapokon. Különleges Bánásmód, II. évf. 2016/3. szám, 67-78. DOI 10.18458/KB.2016.3.67

\begin{abstract}
Absztrakt
A tanulmány témája egy olyan globálisan elérhető központi tudásbázis kialakítása, mely a jövőben agyba épített interfésszel bárki által online elérhető, kereshető. Ennek részletes bemutatása a cél, mely a téma felvezetésével, annak társadalmi oldaláról vett elemzésével kezdődik. Ezt követően az idők kezdetétől napjainkig bemutatásra kerül, hogyan fejlődött, alakult ki a ma ismert formája. A tanulmány végén pedig két megközelítésböl kerül elemzésre: legpesszimistább és legoptimistább verzió, milyen bekövetkezési esélyekkel, illetve milyen tényezők vezethetnek el a bekövetkezésükhöz. Bízunk benne, a tanulmány hozzájárul a legoptimistább verzió elkövetkező években történő megvalósításához.

Jelen tanulmány a Debreceni Egyetem Tehetséggondozó Program „Időkapszula 2016+20” projekt keretében készült; projektvezető: Dr. Mező Ferenc.
\end{abstract}

Kulcsszavak: jövőkutatás, agyinterfész, időkapszula, Debreceni Egyetem

Diszciplina: Informatikai tudományok

\section{Abstract \\ GLOBAL KNOWLEDGE BASE ON SEMANTIC WEB BASICS}

The topic of this study is implementing a globally available, centralized knowledge base, which can be accessed and searched online via brain interface for everyone. Our goal is to describe this plan, first an analysis from the side of society. After this we try to present how the actual form of this knowledge base was developed from the Time Begins to present. At the end of study we describe two way: the most pessimistic and the most optimistic ones, their odds and the facts which increase the realization of odds.

This study was carried out at the University of Debrecen, in the „Time capsule 2016+20" project as part of the Program for Talented Students (DETEP) programme. The supervisor is Ferenc Mező PhD. 
Keywords: future research, brain interface, time capsule, University of Debrecen

Disciplines: Computer Science

E tanulmány egy szemantikus Web alapokon nyugvó globális tudásbázis létrehozásának jövőbeli kilátásait vázolja fel. A jövőkutatás során a Debreceni Egyetem Tehetséggondozó Programjának „Időkapszula 2016+20” projektje keretében Dr. Mező Ferenc által összeállított szempontsort követve az alábbi kérdésekre kerestük a választ:

1. Témafelvetés

1.1. Miért érdekes, fontos ez a téma? Kapcsolódik-e valamilyen nagyobb léptékü társadalmi, tudományos problémához?

1.2. Milyen gyakorlati haszon származhat abból, ha sikeres elörejelzést tudunk adni a témával kapcsolatban?

1.3. Milyen kár származhat abból, ha nem adunk előrejelzést vagy nem sikeres az elörejelzés?

2. Múltbeli tapasztalatok, tendenciák

2.1. A téma első felbukkanása, s körülményei.

2.2. A témával kapcsolatos ismeretek fejlődése (őskor, ókor, középkor, újkor a XX. sz. végéig).

2.3. A témával kapcsolatos ismeretek fejlődésének tendenciái: milyen társadalmigazdasági és/vagy tudományos-technikai körülmények vezetnek nagyobb léptékü változásokhoz.

3. Helyzetkép

3.1. A téma társadalmi elfogadottsága, közismertsége.

3.2. A témával kapcsolatos XXI. századi elméleti-gyakorlati tudásunk, technikai eszközeink.

3.3. Milyen ismeretek hiányoznak még? Milyen lezáratlan kérdések, megoldatlan problémák állnak a téma kutatói előtt? Mivel kapcsolatban (pl. alapfogalmak definiálása, diagnosztikai eljárások érvényessége stb.) alakult ki vita a téma kutatói között?

4. Jövőkép 20 éves időtávlatban

4.1. Mi a legpesszimistább verzió, s miért az?

4.1.1. Milyen események vezethetnek el a legpesszimistább verzió kialakulásához (15 éves időtartamokban)?

4.1.2. Lehetnek-e olyan fordulópontok, krízishelyzetek, amelyek negatív kimenetele a legpesszimistább verzió valószínüségét növelik? Ezek miként előzhetők meg, illetve korrigálható-e a hatásuk, ha már megtörténtek?

4.1.3. Milyen objektíven megfigyelhető jelei lehetnek annak, hogy a legpesszimistább verzió irányába alakulnak az események? Ezek milyen módszerrel/eszközzel regisztrálhatók?

4.2. Mi a legoptimistább verzió, s miért?

4.2.1. Milyen események vezethetnek el a legoptimistább verzió kialakulásához (1-5 éves időtartamokban)?

4.2.2. Lehetnek-e olyan fordulópontok, krízishelyzetek, amelyek pozitív kimenetele a legoptimistább verzió valószínűségét növelik? Ezek hogyan idézhetők elő?

4.2.3. Milyen objektíven megfigyelhető jelei lehetnek annak, hogy a legoptimistább verzió irányába alakulnak az események? Ezek milyen módszerrel/eszközzel regisztrálhatók?

5. Javaslatok a legoptimistább jövőkép-verzió megvalósulása érdekében 


\section{Témafelvetés}

Az elemzésre kiválasztott téma - globális tudásbázis létrehozása szemantikus Web alapokat felhasználva - egyszerübben megfogalmazva egy mindenki által interneten elérhetö könyvtár, adattár létrehozása, mely a tartalomhoz hozzákapcsolt metaadatokkal hatékonyabb keresési, feldolgozási lehetőségekkel vérteződik fel.

Miért érdekes, fontos ez a téma? kapcsolódik-e valamilyen nagyobb léptékü társadalmi, tudományos problémához? A kiválasztott téma a társadalom egy meghatározó problémájára szeretne megoldási lehetőséget előre jelezni. Tekintettel arra, hogy a meglévő tudás megosztása jelentős fontossággal bír nem csak a jövő generációjának, hanem valamennyi ember számára, napi szintü problémákat jelent a felhalmozott tudásbázisok közelérhetőségének biztosítása. Saját tapasztalatból is ismerjük mennyire sokrétü és komplex egy létrejött dokumentum megosztása online. Az egyetem belső hozzáférésű rendszerben kezeli a hallgatói és tudományos dolgozatokat, ezek jelenleg négy elérési szinttel hozzáférhetőek: nyilvános, egyetemi IP címről, könyvtári IP címröl és személyhez kötötten. Ez is tekinthető egyfajta tudományos kihívásnak, de ettől egzaktabb lehet a feltörekvő gráf adatbázisokra történő átállás egy-egy ilyen tárház esetén, valamint ezek összekapcsolása, úton egy globálisan müködő rendszer felé.

Milyen gyakorlati haszon származhat abból, ha sikeres elörejelzést tudunk adni a témával kapcsolatban? Tekintettel arra, hogy a meglévő rendszerek nem más rendszerekkel való együttmüködés jegyében születtek, fontos felhívni a figyelmet a kooperációra, melynek során a meglévő és létrehozandó tudástárak összekapcsolódva globálisan elérhető rendszerré nőhetik ki magukat. E tanulmány célja megbecsülni az elkövetkezendő 20 év fejlődési ütemét és iránymutatást adni a végső cél eléréséhez. Amennyiben sikerül tudatosítani az emberekben mennyire fontos az egymással való információcsere és ennek alapja egy közös, redundanciamentes bázis kialakítása, megteremthetjük a tudásra épülő társadalmat. Fontos, hogy a megszülető előrejelzés a valóságot tükrözve adjon iránymutatást egy ilyen platform létrehozásához, mert ezáltal tudjuk biztosítani, hogy jó úton induljunk el a cél megvalósításához. Bízunk benne, hogy a következőkben bemutatásra kerülő lehetőségek széles tárháza felkelti az olvasó érdeklődését, különösképpen a rendszer kialakításához nélkülözhetetlen szakemberekét, például könyvtárosokét, informatikusokét.

Milyen kár származhat abból, ha nem adunk elörejelzést vagy nem sikeres az elörejelzés? Az elörejelzés hiánya vagy nem teljes értékủ pontossága nem okoz kárt senki számára, viszont azt figyelembe kell venni, ha ténylegesen jól megcélzott iránymutatást sikerül létrehozni, nagyban elősegítheti a társadalom fejlődését, különös tekintettel az oktatásra. Legföképp azért, mert az oktatás területén okoz sok esetben nehézséget egy-egy írott dokumentum beszerzése vagy néhány esetben annak felkutatása. Egy elektronikus tudásközpont megfelelő segédletet biztosíthat mindenki számára a megszerzett tudás elmélyítésére, bővítésére azáltal, hogy szinte korlátlan lehetőségek mellett képes elérni az érdeklödési körének megfelelö dokumentumokat.

\section{Múltbeli tapasztalatok}

A téma első felbukkanása, s körülményei. Az információ megosztás és rögzítés eredete egyidősre tehető az első embercsoportok megjelenésével. Mint közismert az előember is megörökítette emlékezetes pillanatait, erről árulkodnak a fennmaradt barlangrajzok. Ezek kora több ezer évesre datált, vagyis bizonyítható, hogy ténylegesen az első generációkból származó emberek készítették ezeket, többnyire vadászataik megörökítésére. Elképzelhető az is, hogy tették mindezt tanító célzattal az utódaik számára, ezáltal felfoghatóak kezdetleges tankönyveknek is e rajzok. 
A témával kapcsolatos ismeretek fejlödése (öskor, ókor, középkor, újkor a XX. sz. végéig).

A témához kapcsolódó ismeretek kialakulásának kezdete az öskorra tehetö - ahogy ezt az elözőekben felvázoltuk -, amikor is az ösember primitív módon egyszerü barlangképeket készített az általa fontosnak vélt pillanatok megörökítésére (1. ábra).

\section{1. ábra: Ismeretek fejlödése (forrás: a Szerzö)}

\begin{tabular}{|c|c|c|c|c|}
\hline $\begin{array}{c}\text { őskor } \\
\text { i.e. } 4 \text { ezer elött }\end{array}$ & $\begin{array}{c}\text { ókor } \\
\text { i.e. } 4 \text { ezer - i.sz. } 476\end{array}$ & $\begin{array}{c}\text { középkor } \\
\text { i.sz. } 476 \cdot 1517\end{array}$ & $\begin{array}{c}\text { újkor } \\
1517 \cdot 1789\end{array}$ & $\begin{array}{c}\text { jelenkor } \\
18,19 . \mathbf{s z} \text {. }\end{array}$ \\
\hline $\begin{array}{l}\text { barlangrajzok, } \\
27 \text { ezer éve }\end{array}$ & $\begin{array}{c}\text { kõtábla } \\
\text { papirusz: i.e. 4. évezred } \\
\text { Alexandria: i.e. 3. évszázad }\end{array}$ & $\begin{array}{l}\text { Avignon pápai könyvtár: 14. sz. } \\
\text { Mátyás király könyvtár: 15. sz. } \\
\text { első nyomtatott könyv: 15-16. sz. }\end{array}$ & $\begin{array}{c}\text { nagy mennyiségũ } \\
\text { nyomtatott dokumentum }\end{array}$ & $\begin{array}{l}\text { 1890. USA digitális adatfeld. } \\
\text { 1950. elektronikus adattárolás } \\
\text { 1980. internetes adatmegosztás } \\
\text { 2007. MO-on elterjedt az internet }\end{array}$ \\
\hline
\end{tabular}

Az őskori barlangrajzok, -festmények növényekből kivont színezőanyagok és kőporból készült festékek felhasználásával jöttek létre. Több feltételezés is született arra vonatkozóan, vajon mi célból alkották meg ezeket a szimbolikus freskókat. Egyesek szerint a totemhit állatait festették meg, ezt később néprajzkutatók cáfolták azáltal, hogy az ábrázolt állatok maradványait megtalálták a rajzok környezetében. Köztudott, hogy a hitben szereplö élőlényeket nem szabad megölni, illetve megenni. Egy másik elmélet szerint vadászmágiákhoz használták fel ezeket a müveket. Erre több bizonyítékot is találtak kutatók, például a megfestett állatokat több nyílvessző vagy dárda szúrja át. Viszont ezektől elvonatkoztatva tekinthetünk ezekre az alkotásokra egyfajta naplóként, melynek célja lehetett a vadászat pillanatainak megörökítése az utókor generációi számára, mint például a ma használt történelemkönyvek. Ha ezen az irányvonalon indulunk el, akkor az 1. ábra alapján szemléltetett fejlődési periódusokat követhetjük végig az információmegosztás tekintetében az őskortól egészen a jelenkorig.

Következő nagy állomása az ismeretmegosztás fejlődésének az ókor, ahol már a ma ismert formát öltött a tudás átadása, ez pedig nem más, mint a könyvtárak megjelenése. Az időrend betartása végett azonban célszerü az ezt megelőző állapotok tanulmányozása is. Jelen esetben a barlangrajzokról áttérve a kőböl készített táblákra, majd ezt követően a növényi és állati eredetü tekercsek, kezdetleges papírlapok használatára. A leghíresebb kőtáblára feljegyzett szöveg a tízparancsolat, mely az istenhitben nagy jelentőséggel bír. A barlangrajzok után ez vált elterjedtté, mint információhordozó, közvetítő eszköz. Jellemzően vésővel karcolták, vésték rá a szövegeket, ábrákat. A korai ember nem csak táblákra jegyezte fel fontosabb momentumait, kezdetben állati bőröket, majd később különböző növények felhasználásával előállított tekercseket használt e célra. Az egyiptomi nép kiemelkedő szerepet játszott a könyvtárak, levéltárak megalapításában. Kötáblák helyett papirusznádból készített tekercsekre jegyezték le napi ügyekkel kapcsolatos információkat, például könyvelést. Ily módon hoztak létre szépirodalmi, tudományos könyvköteteket is, melyek papirusztekercsekböl álltak. Ezen kívül vallási és egyéb információkat is lejegyeztek az utókor számára. Itt jelent meg elsőként ténylegesen az utókor részére átadandó tudást reprezentáló dokumentum fogalma. Az egyiptomi kultúrához köthető az egyik leghíresebb könyvtár is, az Alexandria városában megalapított dokumentumtár.

Továbbhaladva az időben, elérkezünk a középkorhoz. Itt már ténylegesen a felnövekvő generációnak szánt könyvek, kódexek jelentek meg. Elsősorban a vallási, egyházi kódexek 
domináltak, tekintettel az egyház mély befolyására, de emellett királyi levéltárak, könyvtárak voltak mérvadóak. Pápai dokumentumok örzésére az Avignon-i könyvtárat hoznám fel példaként. Magyar vonatkozásban pedig az igen híres Mátyás királyhoz kapcsolódó Bibliotheca Corviniana emelkedik ki. Itt kézzel készült kódexeket őriztek. Érdekesség, hogy a magyarság eleinte elpusztítani akarta a kolostorokban őrzött könyveket, írásokat. Ennek a vallás befogadása, megismerése vetett véget, ettől kezdve tekinthetjük az információmegosztást tudatosnak. A legnagyobb változást a könyv nyomdai előállítása hozta meg a 15-16. század környékén. Elsőként Gutenberg készített nyomtatott könyvet, ez nem volt más, mint a biblia, viszont a tényleges nagyipari nyomtatás csak az úgynevezett rotációs technológia bevezetésével érkezett el. Ennek során a ma is használt technika segítségével, folyamatos nyomtatást értek el. A nyomólemez henger alakú, így tekercsben halad a papír, nem laponként.

$\mathrm{Az}$ újkorban, köszönhetően a nyomdai eljárás megjelenésének nagy mennyiségben keletkeztek könyvek, folyóiratok és egyéb információt hordozó sajtótermékek. A kor napi életének meghatározója lett a nyomtatott dokumentumok olvasása. Széleskörben tudott terjedni az információ azáltal, hogy mindenki részére, viszonylag gyorsan elérhetővé lehetett tenni egy-egy müvet. Így a tudományos felfedezések hamar el tudtak terjedni világszerte, azáltal, hogy bárki elolvashatta a megjelent cikkeket, ha máshol nem legalább a könyvtárban, vagy könyvklubokban. Erre nehezen lehetett volna megoldást találni a korábbi időszakokban, kézzel ugyanis nem lettek volna képesek felvenni a versenyt egy nyomdagéppel, amely percenként elkészít egy könyvet. Erre a kódexek korában hetek is szükségesek voltak.

A mai kor vívmányai nagyban megváltoztatták a nyomtatott formában történő adattovábbítást. Első állomás e téren az 1890-ben Amerikában tartott népszámlálás, melynek során a begyüjtött információhalmazt elektronikus úton dolgozták fel. Az elektronikus adattárolás viszont később jelent meg, mint úttörö technológia. Az 1950-es években fejlesztették ugyanis ki az első elektronikus adattárolásra alkalmas eszközöket, melyek mágnesdob formájában öltöttek testet. Ezzel kezdetét vette a digitális információterjedés, információ megosztás, mely napjainkban domináns szerepet játszik életünkben. Egy másik nagy mérföldkő az internet megjelenése, ez 1980 környékére tehető. Ez alapjaiban változtatta meg az emberek és az információ kapcsolatát azáltal, hogy szinte bármilye kérdésre választ kaphatunk az interneten. Elmarasztaló adat, hogy Magyarországon csak a 2007-es évtől kezdett elterjedni az internet oly módon, hogy a lakosság körülbelül 38\%-a rendelkezett csak internethozzáféréssel. Szerencsére ez az arány a 2016-os évre jelentősen nőtt, köszönhetően a technika gyors fejlődésének is. Ma már kijelenthető, hogy az információ megosztás legnagyobb csatornája az internetes tartalmakban van.

A témával kapcsolatos ismeretek fejlödésének tendenciái: milyen társadalmi-gazdasági és/vagy tudományos-technikai körülmények vezetnek nagyobb léptékü változásokhoz. A fent ismertetett folyamatokból szembetűnően látszik, hogy az emberi tényezőn kívül a technika fejlődése meghatározó a választott téma előremozdításában. Fontos szerepet játszott az ember személyiségének fejlődése is abban, hogy ma hol tart az információcsere, de elmondható, hogy a jelentôs technikai háttér nélkül sehol nem tartanánk. Ezt arra alapozzuk, hogy ha nem jött volna létre a nyomdagép, akkor nem lennének csak kézzel írott könyveink, nem tudott volna nagy léptékben terjedni az a sok ismeret. Ha pedig internet vagy számítógép nem lenne, akkor az elektronikus adatcsere és ezáltal a tényleges gyors információáramlás nem jöhetett volna létre abban a formában, ahogyan ma ismerjük. Biztosak vagyunk benne, hogy az elkövetkező évek nagy technikai újítása továbbra is meghatározó szerepet fognak játszani abban, hogy elérjünk egy globális tudásbázis kialakulásához, mely az emberiség ismereteit tárolja és teszi elérhetővé bárki számára. 


\section{Helyzetkép}

A téma társadalmi elfogadottsága, közismertsége. A választott téma társadalmi szinten maximálisan elfogadott, illetve a később részletezett jövőbe mutató megoldások támogatottsága is jelentős. Legföképp a szakmabeliek nyitottak a ma még csak sci-fikben létező megoldások iránt, bár meg vagyunk győződve arról, ha holnap valósággá válna, sokan fenntartások nélkül befogadnák.

A témával kapcsolatos XXI. századi elméleti-gyakorlati tudásunk, technikai eszközeink. Tekintve, hogy nem új keletü az információ elektronikusan történő megosztásának víziója, elég széleskörü tudás és technológia született meg ennek minél hatékonyabb elősegítésére. Az arzenált két fó csoportra lehetne bontani: papír alapú dokumentumok elektronikussá konvertálása és eleve elektronikusan létrejövő dokumentumok. E felosztás azért is fontos, mert a felhasználható eszközök, megoldások alapjaiban lehet, hogy hasonlóak, de maga a szemlélet nagyban eltér. Az egyszerübb átláthatóság elérése végett az elérendő céltól elindulva fogjuk felvázolni a rendelkezésre álló palettát. A 2. ábra szemlélteti az említett két csoportból elindulva hogyan jutunk el a tudástárig.

\section{2. ábra: Dokumentumtól a tudástárig folyamatábra (forrás: a Szerző)}

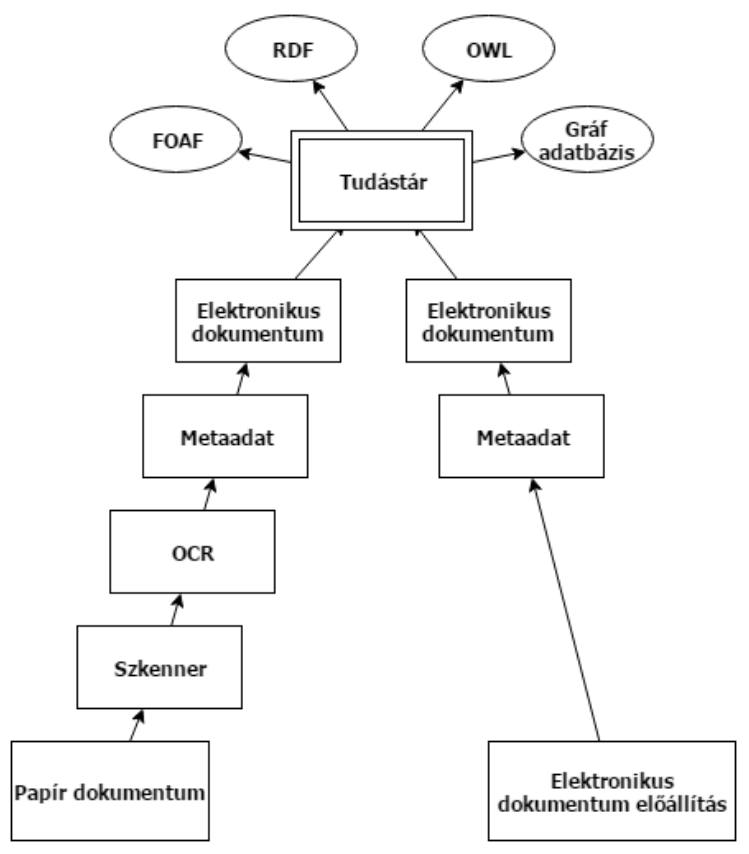

Rövidítések magyarázata: RDF: Erőforrás Leíró Keretrendszer; FOAF: RDF alapú kapcsolatleíró struktúra; OWL: Web Ontológia Leíró nyelv; OCR: Optikai Karakterfelismerés

Központi tudásbázisok szinte minden nagyobb intézményben léteznek, de még egy otthoni videó vagy fénykép archívum is tekinthető ilyen tárhelynek. Ezek kialakítása elsősorban adatbázisra építve valósul meg, azaz a tárolt információ metaadatai valamilyen adatbázisban kerül rögzítésre. Erre a mai nagy mennyiségü adattömegek esetében a gráf adatbázis a legmegfelelőbb, mely képes a szemantikus Web alapjait adó RDF (Resource Description Framerwork) és OWL (Web Ontology Language) kezelésére is, példaként a Neo4j rendszert szeretnénk felhozni, saját tapasztalatból. Könnyen kezelhető, beépített driverekkel rendelkezik, például Java programozási nyelvhez. Az architektúra kiépítésében -tekintve, hogy webes elérhetőségü rendszerek- a SOA (Service Oriented Architecture) alapelvet 
követhetjük. Ez nem jelent mást, mint olyan szoftvertermékek fejlesztését, amelyeknél a komponensek újrafelhasználhatósága biztosított. A végső cél a központi hozzáférhetőségü tudásbázis, mesterséges intelligencia alapon. Ennek megvalósítása több okból sem kivitelezhető jelenleg: biztonsági szempontok, technikai eszközpark. A cél mégis közelinek, illetve elérhetőnek látszik, a DARPA (Defense Advanced Research Projects Agency) tavaly mutatta be első olyan müvégtagját, melyet a páciens gondolatával képes irányítani, illetve sajátjaként érezheti azáltal, hogy a hozzákapcsolt érzékelőktől érkező jeleket úgymond érzések formájában érzékeli. Ez azt jelenti, hogy a használója pontosan úgy érez a végtaggal, mint egy igazi kézzel: a tesztelő $100 \%$ pontossággal tudta megmondani melyik ujját érintették meg. Erre alapozva nem tünik megvalósíthatatlannak az az elképzelés, miszerint az emberi agyhoz kapcsolt internetes interfésszel hozzáférhessünk egy központi tudástárhoz.

Haladjunk tovább! A következőkben a dokumentumok kezeléséhez kapcsolódó meglévő lehetőségeket kívánjuk ismertetni. Elsőként a korábban keletkezett papír alapú információhordozók digitalizálásához nélkülözhetetlen technikai elemeket tekintsük át. Kezdetben egy nyomtatott szerződést beszkenneltünk és kép formájában tároltunk, ez a digitális feldolgozásban már nem elegendő. A piacon többféle, nagyfelbontású szkenner beszerezhető, ezáltal a digitális kép elöállítása maximálisan támogatott. Köszönhetően a technika fejlődésének ma már hasonlóan a szkennerekhez, többféle OCR (Optical Character Recognition) szoftver elérhető, ezek közül mi az ABBYY FineReader alkalmazást használjuk, mely $100 \%$-os nyomtatott karakter felismerést, illetve kézírás felismerést biztosít. Ezen felül metaadatokat is be tudunk vele állítani, mely nélkülözhetetlen a későbbi feldolgozásoknál.

Második lépcső az eleve elektronikusan létrehozott dokumentum, a 2. ábrán jól kitünik, ezzel kevesebb lépéssel juthatunk el a tudástárig. Ez azért fordul elö, mert eleve elektronikus formában hozzuk létre és itt csak a metaadat hozzáadásával kell foglalkoznunk, ezt követően beküldhető a tudástárba.

A legfontosabb tényező a biztonság megteremtése, mely több oldalról is megközelítendő és betartandó. A dokumentum hitelességének igazolása, hozzáférhetőség, biztonsági mentések. Ezekből a hozzáférhetőség kivételével mindegyikre létezik megfelelő megoldás, természetesen a hozzáférést is tudjuk kontrollálni, de nem a központi tudástár szintjén, viszont erről részletesen a következő fejezetben fogunk írni. A hitelességet elektronikus aláírás használatával tudjuk biztosítani, erre többféle megoldás is létezik, legelterjedtebb és széleskörben alkalmazott a tanúsítványra épülő, időbélyeggel ellátott minősített fokozott biztonságú aláírás. Ezt a kézi aláírással egyenértéküként fogadják el hivatalos iratok szintjén is.

Példaként szeretnénk felhozni a FacetedDBLP projektet, mely a számítógép tudományok területén létrejött eredményeket, cikkeket teszi metaadat alapján kereshetővé, böngészhetővé. Fejlesztője az L3S német Kutatóközpont, melynek célja az intelligens adatkeresés és a jövő internetének kidolgozása. A rendszer magját a DOI (Digital Object Identifier) adja, mely az elektronikus dokumentumok minden helyzetben történő azonosítására szolgál. A DOI rendszerben minden fájlnak egyedi azonosítója van és ezekhez több, létező elérési link kapcsolható. Ennek felhasználásával a DBLP átirányít a müködő url-en keresztül a kért fájlhoz. Lekérési folyamat: (FacetedDBLP)-[keresés metaadatokkal]-[a kért fájl kiválasztása](dx.doi.org)-[létező url alapján a hivatkozásra átirányítás]-(igényelt fájl letöltése)

Milyen ismeretek hiányoznak még? Milyen lezáratlan kérdések, megoldatlan problémák állnak a téma kutatói elött? Mivel kapcsolatban (pl. alapfogalmak definiálása, diagnosztikai eljárások érvényessége stb.) alakult ki vita a téma kutatói között? A legnagyobb probléma a technológia kiforratlanságából adódik, nincs megfelelően koordinált háttérrendszer, amely a biztonsági kérdéseket kezelné. Ez erősen megosztja az embereket, vannak, akik kételkednek abban, hogy a legfelső szinten nem fogják úgymond illegális célokra felhasználni a beépített 
technológiát, jelen esetben az agyba épített interfészt. Ha pedig csak egy alsóbb szinten maradunk, a dokumentumok elérhetőségének védelmét tekintve, nem találunk olyan megoldást, mely lehetővé tenné jelenleg a határnélküli, bármilyen adatbázisban történő keresést. A 2016-os évben ott tartunk, hogy meghatározott adattárak ténylegesen nyilvánosan hozzáférhetőek, míg a legtöbb egyetemi és egyéb közadatokat tároló rendszer csak bizonyos célcsoportok részére hozzáférhető. Számunkra legnagyobb problémát az egyetemi rendszerek, sokszor indokolatlan lekorlátozása jelenti, mely a mai oktatási rendszerben az elképzeléseink szerint nélkülözhetetlen lenne. Segítségével más hallgatók munkáiból tanulhatnánk, illetve okulhatnánk. Véleményünk szerint a ma elérhető szövegbányászati módszerekkel biztosítható lenne a sokszor kifogásként felhozott indok, miszerint a plágium elkerülése végett nem nyilvánosak e tárhelyek. Erre rácáfol az is, hogy a doktori tézisek ténylegesen elérhetőek nyilvánosan.

Másik lemaradás, mely tekintetében jelentős előrelépéseket már elértek, az agyba építhető interfész, melynek célja az állandó online kapcsolat elérése lenne. Ezáltal a megtanult ismereteink könnyedén bővíthetőek lennének, anékül, hogy sok időt kellene eltöltenünk tanulással. A legfrissebb kutatások rávilágítottak arra, hogy az agy tárolókapacitása 100 terabyte, de mivel az adatok hozzáférése nem számítógép alapú, ezért ez nem tekinthető 100 \%-os becslésnek, viszont ha létrehoznak egy olyan egységet, amely segíti a rendszerezést, adatfeldolgozást, akkor ez a tárhely széleskörü lehetőségeket rejt magában. Példaként felhozták a cikkben, hogy egy átlagos interneteléréssel egy 500 oldalas könyv feldolgozása 2 másodpercbe telne.

$\mathrm{Az}$ előbb részletezett chip kifejlesztésében nem tud mindenki részt venni, de egy hatékonyabb és összekapcsolható adattárakból álló központi tárhely kialakításában bárki részt vehet. Méghozzá elég egyszerüen, csupán be kell tartania az elektronikus dokumentum megosztásánál, feltöltésénél a korábban megemlített néhány szabályt. Minden dokumentumhoz csatolni kell metaadatokat, mely a későbbi feldolgozást teszi lehetővé. Amennyiben szükséges hitelesíteni kell, például egy elektronikus aláírással. Szemantikus weben alapuló leírást is célszerű mellékapcsolni, ez lehet egy RDF vagy FOAF gráf, mely leírja a szerző és munkáinak kapcsolatát, esetleg már meglévő dolgozatokhoz történő kapcsolását.

\section{Jövőkép 20 éves időtávlatban}

Az alábbiakban kísérletet teszünk 20 éves időtávlatban a legpesszimistább, illetve a legoptimistább jövőkép felvázolására.

\section{Mi a legpesszimistább verzió, s miért az?}

Az elképzelésünk szerint a legpesszimistább jóslásba az tartozna bele, hogy a túlzottan gyors technikai fejlődés, valamint a mellette párhuzamosan futó, de lemaradó biztonsági elvek hatására megtörik az előrehaladás és a társadalom nagy része visszatér a hagyományos papír alapú dokumentumkezeléshez. Vagyis ezáltal nemhogy a globálisan elérhető tudástár nem, de még a papírmentes ügyintézés sem valósul meg. Ennek legmagasabb kockázata pedig magában a fejlődésben keresendő, mivel az emberek szinte lemaradnak a technika mellett, legfőképp a biztonságot szem előtt tartva.

Milyen események vezethetnek el a legpesszimistább verzió kialakulásához (1-5 éves idötartamokban)? Tekintve, hogy ma is vannak jelek arra vonatkozóan, hogy a biztonság sokszor mellékes szerephez jut, ha a technológia fejlődése a ma ismerttől is gyorsabb léptéküre emelkedik, előfordulhat, hogy a biztonság -akár emberi életek tekintetébenmásodlagos, vagy ettől is lentebbi szintre kerül annak érdekében, hogy megvalósuljon egy- 
egy fejlesztés. A következőkben ennek kialakulását szeretnénk bemutatni 5 éves bontásokban a következő 20 évre vetítve.

Az első ciklusban mindenképp arra lehet következtetni, hogy a technikai fejlödés eljut egy olyan szintre, amikor az emberek be vannak kapcsolva a számítógépes architektúrákba, vagyis az emberi szervezetbe a ma ismertnél intelligensebb szenzorok lesznek beépítve, például szívritmus szabályozó, ami online kapcsolatban van az egészségügyi szervezettel, vagy különböző azonosítást segítő chipek. Eleinte mindenki hasznosnak találja majd ezeket az eszközöket, egészen addig, amíg ki nem alakul egy megfigyelési botrány, mint például a közismert NSA tekintetében. Erre viszont a feltételezéseink alapján az első 5 évben nem igazán kell számítani. Mivel egy új és hasznos segédeszköz kerül látószögbe, az emberek nagy többségben alkalmazni fogják ezeket. És hogy a témához is kapcsolódjunk, a dokumentumok kezelése egyre inkább átkerül az elektronikus térbe, amely ugye nem megfelelően fejlesztett rendszerek által sebezhetővé tehet minden személyes anyagot.

Lépjünk előre még 5 évet, most már a következő 10 éves periódusban járunk, erre az időszakra kiforrottabbá vált a korábban felvázolt szenzorokkal felszerelt ember és elektronizált dokumentumtár mikéntje. Ilyen hosszú távon elő kell, jöjjön néhány biztonságkritikus probléma is, például kiszivárgott személyes információk, esetlegesen kórházi kartonok. De ennek ellenére a további fejlődés eredményeként biztosak vagyunk benne, hogy a legtöbb ingatlan okos otthonná fejlődik és ehhez nélkülözhetetlen a további személyes információk központosított, elektronikus tárolása, kezelése. Vegyük például a beléptető rendszerek kérdését, 10 éve belül biztosan megjelennek az átlagember számára is elérhető ujjlenyomat alapú ajtózárak vagy az arcfelismerő kamerák. Ezek még az eddigieknél is magasabb kockázattal járnak, ha nem megfelelő a biztonsági fejlesztés. Az online elérhető kamerarendszerekröl több esetben is kiderült, hogy biztonsági résekkel rendelkeznek a központi eszközeik, ezáltal pedig feltörhetőek, azaz egy felkészültebb szakember bármikor benézhet egy-egy házba, anélkül, hogy a bentlakók ebböl észlelnének bármit. Hasonló kockázatot hordozhatnak a felső alapú tárolók, ahol a családi, vállalati titkok kerülhetnek veszélybe.

A 15 éves periódusban a technikai fejlődés a maximumához közelíthet azáltal, hogy megjelennek az agyba építhető interfészek, melyekkel az internetre csatlakozva elérhetjük a központi tudástárak tartalmát. Gondolatok alapján tanulhatunk új készségeket, viszont ha nem a biztonság megtervezésével kezdődnek ezek a fejlesztések, akkor az elkövetkezőkben eljuthatunk oda, hogy aki hozzáfér ezen chipekhez, az szinte bármit manipulálhat az emberek tudatában. Kiszivárognak olyan jelentések, melyek alátámasztják a meglévő titkosítási és azonosítási rendszerek hiányosságait, melyek hatására a társadalom egy része ki akar majd lépni az elektronikus világból, az így tárolt információit akár újra papír alapon akarja majd tudni. Azáltal, hogy ez egy igen hosszú távú, jövőbemutató elképzelés egyenlőre a mostani viselkedésekből, illetve saját tapasztalatokból lehetne felállítani olyan mutatókat, amelyek megcélozzák mi vezethet a teljes bukáshoz.

Ennek felvázolását az utolsó 5 éves periódusba szeretnénk beépíteni, mely már az elkövetkező 20 évet öleli fel. Közismert tény, hogy a jelen években több globális probléma merült fel az elektronikus tárolórendszerekkel kapcsolatban, legfőképp a biztonság rovására. Elsőként az NSA ügy robbant ki, melynek során nyilvánosságra került, hogy a legelterjedtebben használt titkosítási rendszer, az OpenSSL tartalmazott olyan kiskapukat, melyekkel a webes kapcsolatok biztonsága, titkosítottsága sérült. Másik ilyen globális méretü veszélyforrás a vírusok térfeléről érkezik, melyek a mai rendszerekben is igen nagy kockázatot jelentenek. Kiemelnénk a titkosító vírust, mely idén, illetve a tavalyi évben több egészségügyi intézmény rendszerét is megfertőzte, ezzel legtöbbüket hetekre müködésképtelenné téve. Amennyiben nem volt megfelelő belső védelem, illetve biztonsági 
mentés a károk szinte visszafordíthatalanok. Tekintettel arra, hogy egyre több kórházi eszköz csatlakozik online módon számítógépes architektúrához, a betegek élete is veszélybe kerülhet.

A fenti ismertető alapján a legfontosabb mérő a biztonság betarthatósága, egy kiépített rendszer tekintetében az milyen biztonsággal tudja ténylegesen védett módon kezelni, tárolni az elhelyezett adathalmazokat. A bukáshoz vezető úton el is érkezünk ahhoz a ponthoz, amikor már nincs visszaút, ha előfordul tömegesen adatkiszivárgás, vagy hibás rendszerek miatt emberélteket követelő események, akkor teljes biztonsággal kijelenthetö, a legtöbb ember nem kíván tovább részese lenni az elektronikus közösségnek és legfőképp nem bízza féltve örzött adatait olyan tárházakra, ahol nem biztosított a megfelelő kezelés, tárolás.

Lehetnek-e olyan fordulópontok, krízishelyzetek, amelyek negatív kimenetele a legpesszimistább verzió valószinüségét növelik? Ezek miként elözhetök meg, illetve korrigálható-e a hatásuk, ha már megtörténtek? Ahogyan az előbbiekben felvázoltuk a bukás felé vezető utat, kitünik, hogy a komoly kompromittáló események nagyban hozzájárulhatnak a legpesszimistább verzió kialakulásához. Ezekből kiemelkedők azon esetek, amikor emberi életek múlnak egy-egy hibán. Ez leginkább az egészségügyet, illetve olyan területeket érint, ahol közvetlen vagy közvetett emberéleteket veszélyeztethet a hiba, ezeket szaknyelven kritikus rendszereknek nevezzük. Például atomerőmüvek, kórházak, személyes adatokat kezelő rendszerek. Amennyiben a központi tudásbázist úgy képzeljük el, hogy nem kizárólag tananyagokat teszünk központilag elérhetővé, hanem mindent, természetesen megfelelő jogosultsági szintek betartásával, akkor ez teljesen valós veszélyforrás lehet.

Ennek elkerülésére a leghatékonyabb módszer, ha a rendszerek tervezését a biztonságkritikus pontok felmérésével kezdjük és ezekre azonnal megoldásokat is készítünk, majd ezt követően kezdjük fejleszteni a tényleges rendszert. Ettől hatékonyabb megoldást jelenleg nem tudunk realizálni. Viszont, ha arról az oldalról közelítjük meg, hogy ha már megtörténik egy, úgymond katasztrófa, akkor sem feltétlen kell mindent leírni, mivel ezeket felhasználva jobbá tehetjük az adott rendszereket, természetesen a keletkezett károk függvényében elöfordulhat, hogy alapjaiban rengeti meg a bizalmat e rendszerek felé. De az megállapítható, ha komolyan figyelembe vesszük a biztonság kérdését, akkor nem következhetne be olyan esemény, amely hatására a jövőbeli elképzelés ellenkezője válik valóra. Erről viszont a következő fejezetben fogunk részletes leírást adni, az optimista jövőkép esetén.

Milyen objektíven megfigyelhetö jelei lehetnek annak, hogy a legpesszimistább verzió irányába alakulnak az események? Ezek milyen módszerrel/eszközzel regisztrálhatók? Erre nincs konkrét mérési lehetőség, megfigyelésekre alapozva lehet következtetéseket levonni. Például, ha egyre kevesebben kezdik el használni az elektronikus publikációs rendszereket, emellett egyre többen térnek vissza papír alapú dokumentáláshoz, akkor kijelenthetö, hogy nem jó irányban haladunk. Még egy fontos momentum, mely nagyban a legpesszimistább opció felé terelheti az emberiséget, ez pedig ha minél többször derülnek ki komoly hiányosságok e tárhelyekről, rendszerekről. Ez könnyen mérhető, követni kell az eseményeket, figyelni a felbukkanó komoly problémákat előidéző eseményeket és még a probléma elhatalmasodása elött beavatkozni.

\section{Mi a legoptimistább verzió, s miért?}

A ma elképzelhető legoptimistább verzió, ha minden elektronikus alapon keletkezik, tárolódik és ezen felhalmozott értékek az internet révén bárkivel megoszthatóak, bárki számára hozzáférhetőek a megfelelő jogosultságok betartása mellett. Ennek indoka a társadalom és a tudományok gyors fejlődése, illetve az emberek tudásvágyának kiszolgálása. Azáltal, hogy minden meglévő és újonnan keletkező tanulmány, dolgozat vagy egyéb tudományos anyag elérhetővé válik, egyszerübben és biztosabb alapokon valósítható meg az oktatás. Ettől kicsit magasabb szintre lépve, ha minden elektronikus dokumentum, a 
megfelelö intézkedések - hozzáférési jogosultságok - mellett elérhetővé válik, akkor határtalan lehetőségek nyílnak meg mindenki előtt, például vizsgálati eredményekben történő kutatás, bárhonnan elérhető dokumentumok. A vízió pedig nem más, mint, hogy e tárházak agyba épített interfészekkel, állandó online kapcsolattal elérhetőek legyen bárki számára.

Milyen események vezethetnek el a legoptimistább verzió kialakulásához (1-5 éves időtartamokban)? Kijelenthető, hogy ma már ennek megvalósulása felé haladunk azáltal, hogy egyre több területen a papír alapú dokumentumokat felváltja az elektronikus. Szinte minden felsőoktatási intézmény rendelkezik részben nyilvános dokumentumtárral. A könyvtárak anyagai és a nyilvánosan elérhető információk elektronikus formátumban elérhetőek és ezek köre napról-napra bővül. A tényleges vízió eléréséhez még rengeteg fejlesztés szükséges, ma még csak alapvető eszközök állnak rendelkezésre.

Több kutatás szerint az agyba építhető internetes interfész az elkövetkező években valósággá válhat, bízva ebben a következő 10 évre datálható ennek megvalósulása. Ez pedig nagyban segítené az alapötlet megvalósulását, miszerint mindent online, bármikor, bárhonnan elérhetnénk, akár egy gondolatunkkal.

Haladva a cél felé a biztonságot szem előtt tartva, a jelenlegi tudásunkat felhasználva az előbb felsoroltaktól nagy volumenben eltérő eseményeket nem igazán lehet kiemelni. Biztonság, szemantikus webre építkező publikálás, közös tudásbázis építése, az információk nyilvános közzététele vagy megfelelő jogosultságok felépítése tudja segíteni az optimista megvalósulást.

Lehetnek-e olyan fordulópontok, krízishelyzetek, amelyek pozitív kimenetele a legoptimistább verzió valószínüségét növelik? Ezek hogyan idézhetök elö? Fordulópontként kiemelhető az agyi interfész területén megjelenő jövőbeli fejlesztések, melyek, ha sikeresen zajlanak és megvalósul a beépíthető internetkapcsolat, akkor az messzemenőkig előreviszi a megvalósítást. Ennek előidézése leginkább a résztvevő kutatókon és az őket segítő nagyvállalatokon múlik. Tekintettel arra, hogy igen jeles eredményeket értek eddig el, bízhatunk a folytatásban is.

Milyen objektíven megfigyelhetö jelei lehetnek annak, hogy a legoptimistább verzió irányába alakulnak az események? Ezek milyen módszerrel/eszközzel regisztrálhatók? A legpesszimistább eseményeket megfigyelve, azok éles ellentétei mutathatják az optimista jövőkép felé haladó irányt. Ezek leginkább a papír alapú dokumentumok kiszorítása és az elektronikus adatkezelés térhódításának növekedése, illetve az egyre megbízhatóbb tárházak kialakításai lehetnek. Mérésére a populáció elmozdulása az elektronikus adatkezelés irányába mérőszám, százalékos érték növekedése lehet a legalkalmasabb. Magyar felmérés szerint a megkérdezett cégek esetén $40 \%$ alatti volt a papír dokumentum aránya az elektronikushoz képest. 2004-es nemzetközi felmérés alapján a világ adathalmazának legalább 90 \%-a elektronikus formában jelent meg, melyek soha nem lettek kinyomtatva.

\section{Javaslatok a legoptimistább jövőkép-verzió megvalósulása érdekében}

Ahhoz, hogy a legoptimistább jövőképből valóság nőhessen ki, az alábbiakat mindenképp szükséges megteremteni:

- Minden újonnan interneten megjelenő, megosztani kívánt tartalmat a szemantikus Web alapjait betartva, metaadatokkal felvértezve szükséges publikálni.

- Törekedni kell a már meglévő tárházak összekapcsolhatóságát kialakítani, valamint az elhelyezett dokumentumok korlátozás nélküli megosztását biztosítani, betartva a jogosultságokat, ahol szükségesek. Azaz központi jogosultságkezelő rendszert is fel kell állítani a tárházak mellé.

- Törekedni kell a technikai fejlesztések területén az agyba építhető interfész megvalósítására, természetesen a biztonságok leginkább szem előtt tartva. 


\section{Irodalom}

Budai Egészségközpont. (2012). Mennyi lehet az emberi agy kapacitása?. BHC. (Letöltés: 2016. 05. 20. Web: http://bhc.hu/magunkrol/sajtoszoba/sajtokozlemenyek/2012/hirlevelcikkek/agy-kapacitasa)

DARPA. (2015). HAPTIX Starts Work to Provide Prosthetic Hands with Sense of Touch. DARPA. (Letöltés: 2016. 05. 20. Web: http://www.darpa.mil/news-events/2015-02-08)

Drake, P. (2000). How many bytes can the human brain hold?. Indiana University. (Letöltés: 2016. 05. 20. Web: http://www.madsci.org/posts/archives/2000-05/958764378.Ns.r.html)

Fensel, D. (2007). Computer Science in the 21st Century. University of Innsbruck. (Letöltés: 2016. 05. 20. Web: http://wi-consortium.org/wicweb/pdf/Dieter\%20Fensel.pdf)

Hlács, F. (2015). Tapintásérzékelésre képes müvégtagot mutatott be a DARPA. HWSW. (Letöltés: 2016. 05. 20. Web: http://www.hwsw.hu/hirek/54512/darpa-muvegtag-tapintasrobotika.html)

Net1: L3S Research Center. (Letöltés: 2016. 05. 20. Web: https://www.13s.de/home)

Net2: FACETED DBLP. (Letöltés: 2016. 05. 20. Web: http://dblp.13s.de)

Ötvös, Z. (2014). Agyként működik az új szuperchip. NOL.HU. (Letöltés: 2016. 05. 20. Web: http://nol.hu/tud-tech/emberi-agykent-mukodik-az-uj-szuperchip-1479021)

Rojahn, S. Y. (2012). A brain implant that thinks. MIT. (Letöltés: 2016. 05. 20. Web: https://www.technologyreview.com/s/429204/a-brain-implant-that-thinks)

Rotenstreich, S.: The George Washington University. (Letöltés: 2016. 05. 20. Web: https://www.seas.gwu.edu/ shmuel/WORK/Differences/Chapter\%203\%20$\% 20$ Sources.pdf) 